\title{
MONITORING AND SIMULATION OF THE UNSTEADY STATES IN CONTINUOUS CASTING
}

\author{
OPAZOVANJE IN SIMULACIJA NESTABILNIH POGOJEV MED \\ KONTINUIRNIM LITJEM
}

\author{
René Pyszko $^{1}$, Zdeněk Franěk $^{2}$, Miroslav Příhoda ${ }^{1}$, Marek Velička ${ }^{1}$, Kamil Sikora ${ }^{1}$ \\ ${ }^{1} \mathrm{VŠB}$ - Technical University of Ostrava, Faculty of Metallurgy and Materials Engineering, Department of Thermal Engineering, \\ 17. listopadu 15, 70833 Ostrava, Czech Republic \\ ${ }^{2}$ Silesian University in Opava, School of Business Administration, Univerzitní square 1934/3, 73340 Karviná, Czech Republic \\ rene.pyszko@vsb.cz
}

Prejem rokopisa - received: 2016-08-01; sprejem za objavo - accepted for publication: 2017-09-26

doi:10.17222/mit.2016.235

\begin{abstract}
Continuous casting comprises thermal, mechanical and chemical processes running in a complex system that contains a number of elements, such as a solidifying steel strand, a mould with an oscillation mechanism, a withdrawal mechanism, a water cooling sub-system with nozzles, several control sub-systems, etc. An external observer might see the process as robust and stable, but in reality there are fluctuations in the internal thermal and mechanical quantities, reflected in the structure and quality of the product. The research on unsteady behaviour of the quantities such as a solidifying strand temperature field, solid shell thickness and metallurgical length was conducted using an industrial diagnostic system DGS complemented with special measurement equipment and a thermal numerical model. Selected results of the monitoring and simulation of the non-standard process states are shown and analysed in the paper. Methods for determining the boundary conditions for the numerical model are also presented. The effect of the Leidenfrost phenomenon on the heat-transfer coefficient during water cooling by nozzles is also discussed. Since the determination of precise and immediate boundary conditions has technical limits, the model provides only smoothed values in time and space. As knowledge of the instantaneous state of the fluctuating process is a prerequisite for achieving quality and defect-free production, it is appropriate to complement the thermal numerical model by on-line monitoring of the machine's internal state. The results of the simulations are closely linked to the real process data.

Keywords: continuous casting, monitoring, on-line simulation, boundary conditions
\end{abstract}

Kontinuirno litje obsega termične, mehanske in kemične procese, ki tečejo v kompleksnem sistemu, ki vsebuje vrsto elementov, kot so: strjujoča se jeklena žila (gredica), kokila z oscilacijskim mehanizmom, izvlečni mehanizem, vodno hlajenje s podsistemom hladilnih šob, več kontrolnih podsistemov itd. Zunanji opazovalec lahko vidi proces kot robusten in stabilen, toda $v$ resnici imamo vrsto fluktuacij (nihanj) internih termičnih in mehanskih veličin in kakovosti produkta (nastajajoče konti lite gredice). Raziskave (časovno) nestabilnega obnašanja veličin, kot so: temperaturno polje strjujoče se konti gredice, debelina trdne skorje in metalurška dolžina, so avtorji prispevka izvajali z industrijskim diagnostičnim sistemom (DGS), dopolnjenim s specialno merilno opremo in termičnim numeričnim modelom. V članku avtorji predstavljajo izbrane rezultate analiz, opazovanja in simulacije nestandardni procesnih stanj. Prav tako predstavljajo metode določevanja robnih pogojev za numerični model. Diskusija obsega tudi t.i. Leidenfrostov fenomen in njegov vpliv na koeficient prenosa toplote med vodnim hlajenjem s šobami. Za natančno določitev vsakokratnih robnih pogojev obstajajo tehnične omejitve. Zato so v postavljenem modelu uporabljene le zglajene vrednosti v realnem času in prostoru. Poznavanje trenutnega stanja ves čas spreminjajočega stanja, je predpogoj za doseganje kvalitetne proizvodnje brez napak. Zato je primerno uporabljati termični numerični model s tekočim (on-line) oz. neposrednim spremljanjem internega stanja na konti livni napravi. Predstavljeni rezultati so tesno povezani $\mathrm{z}$ realnimi procesnimi podatki.

Ključne besede: kontinuirno litje, monitoring, on-line simulacija, robni pogoji

\section{INTRODUCTION}

Continuous casting (CC) is currently the leading technology of liquid steel processing into solid semifinished products. The process is typically unstable. Internal state variables change due to operator control interventions into casting and cooling parameters, but the variables also fluctuate spontaneously either in a random or quasi-periodic way. The most effective technique to predict the process state is based on continuous measurement and evaluation of the internal quantities in the continuous casting machine (CCM) that helps achieve quality and defect-free production. ${ }^{1}$ Modern casters are also equipped with a numerical model of the strand solidification and cooling, which is functioning as "a soft- ware sensor" for detecting quantities immeasurable by other technical means, such as solid shell thickness., ${ }^{2,3}$ Numerical models require boundary conditions that are usually determined with data from the monitoring and control system and data from laboratory measurements.

The aim of the research was to investigate the behaviour of the $\mathrm{CC}$ process based on real process data as well as results of specific experimental measurements and simulations. The paper focuses on the kinetics of the strand temperature field. To achieve the required quality of the product and to avoid failures such as breakouts, it is desirable that the temperature field of the solid shell is stable and uniform, in both the transverse and longitudinal directions. Non-defect billets are a prerequisite for quality sheets or pipes made from them and conse- 
quently for impeccable final products. ${ }^{4}$ Since the occurrence of non-standard states due to changes in casting parameters cannot be eliminated in the actual casting process, the investigation of their influence on the strand temperature field kinetics is important in terms of the quality and safety of production.

\section{EXPERIMENTAL AND SIMULATION RESEARCH}

Experimental research was conducted in a real plant as well as in a laboratory using an extensive experimental equipment and software. The industrial monitoring and diagnostic system DGS was utilized for gathering the values of internal variables in the caster during experiments. The mould is the most important part of the CCM, which determines the quality of the final product. The system DGS has been developed by the company DASFOS in co-operation with the authors from VŠB - Technical University of Ostrava (both from the Czech Republic) and was implemented at block and billet casters of round and rectangular formats in Třinecké železárny and Železárny Podbrezová. ${ }^{5}$ The algorithms of DGS are based on measurements and analyses of temperatures in the mould wall and friction between the strand and the mould.

Up to 30 thermocouples of type $\mathrm{E}(\mathrm{NiCr}-\mathrm{CuNi})$ were installed in the round mould with a diameter of $520 \mathrm{~mm}$ in a single horizontal level $390 \mathrm{~mm}$ from the mould upper edge around the mould perimeter for the purpose of breakout and quality prediction (Figure 1). The system DGS also recorded the process variables received from the caster control system, e.g., cooling water temperature and flow rate, liquid steel level and temperature, casting speed, etc. All data were stored with a period of $5 \mathrm{~s}$.

During experimental campaigns a special measurement equipment was also used, which complemented the system DGS. Moulds of the round format $\varnothing 520 \mathrm{~mm}$ were fitted with an additional 12 thermocouples installed

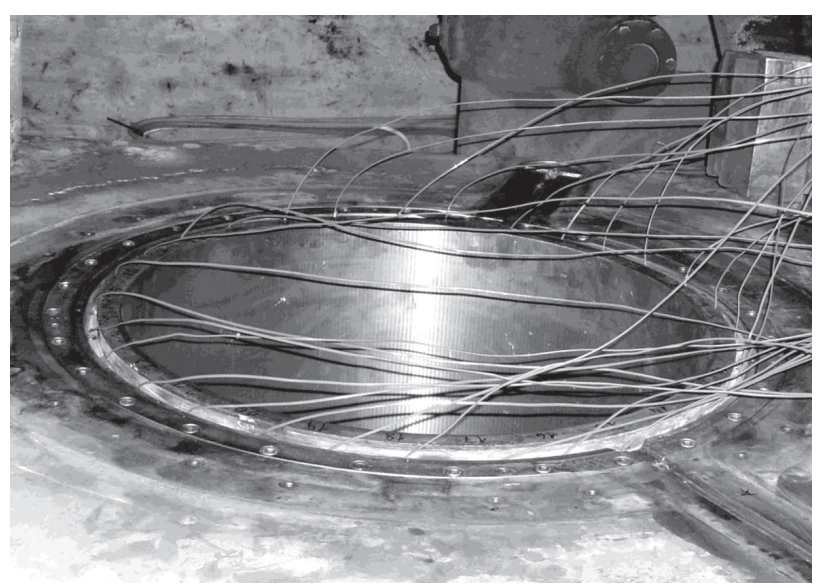

Figure 1: Thermocouple leads mounted in the mould (Source: DASFOS) in two vertical lines at distances from the mould upper edge of $(116,236,356,426,506$ and 586) mm. Six sensors were on the side of the outer radius (OR) and another six sensors on the inner radius (IR) side. ${ }^{6}$

Below the mould, the strand surface temperatures were measured by means of optical pyrometers. Three pieces of ratio pyrometers were used, namely Raytek Marathon MR1SB (a span of 700-1800 ${ }^{\circ} \mathrm{C}$ ) and MR1SA (a span of $600-1400{ }^{\circ} \mathrm{C}$ ).

Due to significant delays in the caster caused by the strand withdrawal, for the purpose of evaluation all the data were transformed from a database of time series to a database of the samples belonging to strand virtual cross sections. Special software was developed for this purpose, which interpolated and integrated the values with respect to the point or length interval, where the particular quantity was acting in the caster. The algorithm was designated as "data aggregation". 7,8 Each record in the aggregated database contained values that characterised the history of the strand section during moving through the caster.

Off-line and on-line versions of thermal numerical models were developed at the Department of Thermal Engineering at VŠB - TU Ostrava. The on-line model was used during the experimental work for evaluating the strand temperature field, the thickness of the solid shell and the length of liquid and mushy core of the strand, called the metallurgical length. A prototype of the advanced diagnostic system "DGS-DMT" consisting of the system DGS linked with the thermal numerical model was developed in the company DASFOS in cooperation with VŠB - TU Ostrava. The system was successfully tested at the round block caster in Třinecké železárny.

The thermal model is based on the Fourier-Kirchhoff Equation (1):

$$
\frac{\mathrm{D} t}{\mathrm{~d} \tau}=a \cdot \nabla^{2} t+\frac{q_{V}}{c_{p} \cdot \rho}\left(\mathrm{K} \cdot \mathrm{s}^{-1}\right)
$$

where $a\left(\mathrm{~m}^{2} \mathrm{~s}^{-1}\right)$ is the thermal diffusivity of steel, $q_{V}$ $\left(\mathrm{W} \mathrm{m}^{-3}\right)$ is the volumetric internal heat source of the latent heat of solidification, $c_{p}\left(\mathrm{~J} \mathrm{~kg}^{-1} \mathrm{~K}^{-1}\right)$ is the specific heat capacity, $\rho\left(\mathrm{kg} \mathrm{m}^{-3}\right)$ is the density and $\mathrm{D} t / \mathrm{d} \tau$ is the substantial derivative of temperature by time. All the thermophysical parameters of the steel are functions of temperature.

The model uses a 3D explicit finite-volume method. The calculated volume contains the whole strand from the steel level in the mould down to the cutting device. The main result of the model is the strand temperature field. The liquid, mushy or solid phase of each steel element is identified by comparing the element temperature with the steel liquidus and solidus temperatures. The numerical model was verified by comparing the calculated temperatures of selected surface elements to temperatures measured using optical pyrometers. 
To solve the numerical problem, boundary conditions are required. Besides the initial, geometrical and physical conditions, surface conditions must be determined. The average heat flux $q_{\mathrm{m}}$ in the mould was derived from measured cooling water parameters using the following Equation (2):

$$
q_{\mathrm{m}}=\frac{1}{A_{\mathrm{m}}} \cdot \rho \cdot Q_{\mathrm{w}}\left(c_{\mathrm{p}, 2} \cdot t_{2}-c_{\mathrm{p}, 1} \cdot t_{1}\right)\left(\mathrm{W} \cdot \mathrm{m}^{-2}\right)
$$

where $A_{\mathrm{m}}\left(\mathrm{m}^{2}\right)$ is the area of the mould working surface, $\rho\left(\mathrm{kg} \mathrm{m}^{-3}\right)$ is the water density at the position of the flow rate sensor, $Q_{\mathrm{w}}\left(\mathrm{m}^{3} \mathrm{~s}^{-1}\right)$ is the water flow rate, $t_{1}$, $t_{2}\left({ }^{\circ} \mathrm{C}\right)$ are the temperatures of inlet and outlet cooling water, $c_{\mathrm{p}, 1}, c_{\mathrm{p}, 2}\left(\mathrm{~J} \mathrm{~kg}^{-1} \mathrm{~K}^{-1}\right)$ are the mean specific heats of water at temperatures $t_{1}, t_{2}$ calculated by integration of the immediate heat capacity for the interval from $0{ }^{\circ} \mathrm{C}$ to the actual temperature.

Heat flux in a real mould varies along the mould length and perimeter. The heat flux layout in mould walls was compiled from the average heat flux $q_{\mathrm{m}}$ using measured temperature layout in a mould wall. Figure 2 shows an example of the vertical temperature profiles on the sides of the mould outer radius (OR) and the inner radius (IR) measured during casting the steel with $0.4 \%$ of mass fractions of $\mathrm{C}$. The temperature profiles in the graph were evaluated from five of six thermocouples on each side. The highest placed thermocouples were not used as they were occasionally above the steel level. The temperature profiles show that the strand was pushed to the OR side at the lower part of the mould. This was individual to the specific mould and casting parameters. Temperature profiles are influenced by the mould wear, geometrical adjustment of the casting arc, submerged nozzle position, etc. Several hundred heats were measured and an extensive database of temperature profiles was created.

The demanding task was to determine the $3^{\text {rd }}$-kind condition under spraying nozzles in the secondary cooling zone. The condition represents a heat-transfer coefficient $(\mathrm{HTC}, \alpha)$. An original laboratory device was developed, which utilised special sensors, either a

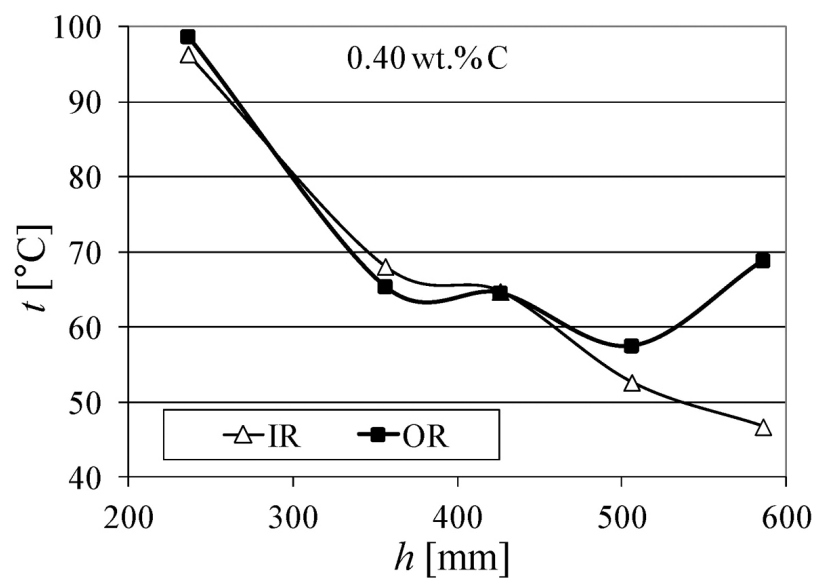

Figure 2: Vertical temperature profiles in the mould

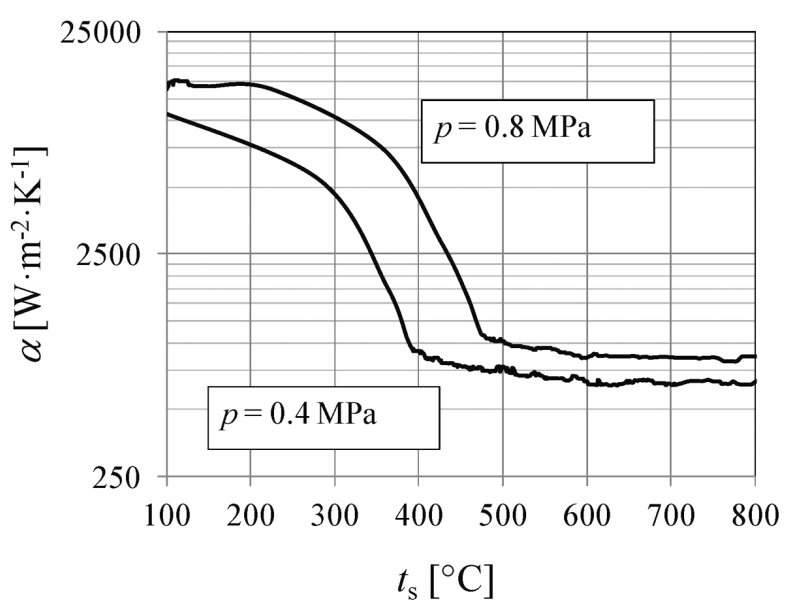

Figure 3: Measured dependences of HTC on surface temperature

directly or indirectly heated probe with a stainless-steel core, which was repeatedly heated by electric current and then exposed to spraying while temperatures in the core were sensed. HTC was then obtained by solving an inverse problem of heat conduction. The nozzle was mounted opposite to the probe on the arm of the industrial robot, which moved the nozzle to discrete positions and, step by step, the entire sprayed area was scanned. At each single position, the dependence of HTC on the surface temperature for specific water pressure was obtained. An example of such dependences for two values of pressure is in Figure 3 for the nozzle JATO 3065 at a distance of $100 \mathrm{~mm}$ between the nozzle and the sensor. The dependences are typically non-linear due to the Leidenfrost phenomenon. The value of the Leidenfrost temperature point $\left(400{ }^{\circ} \mathrm{C}\right.$ for pressure of $0.4 \mathrm{MPa}$ and $480{ }^{\circ} \mathrm{C}$ for $0.8 \mathrm{MPa}$ ) depends, apart from the water pressure, on the local spray intensity, size and kinetic energy of water drops, surface roughness, oxide layer on the surface, etc. ${ }^{9}$

Figure 4 represents the obtained distribution of HTC over a square part of the sprayed area for a surface temperature of $800{ }^{\circ} \mathrm{C}$ and a water pressure of $0.4 \mathrm{MPa}$ for the nozzle type and the distance specified above. This characteristic is one example of the extensive set of

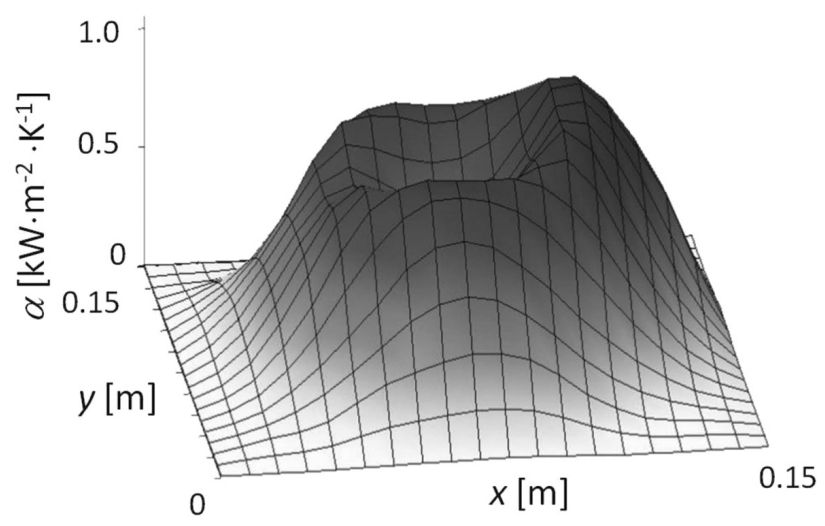

Figure 4: Layout of heat transfer coefficient on surface 
characteristics obtained with laboratory measurements for all the nozzles and parameters used in the caster.

In the thermal model of the round format caster, unlike a slab caster, the influence of the rollers to the heat removal can be neglected. This is due to the relatively small number of rollers compared to the slab machine and the small area of the contact between the rollers and the strand.

\section{RESULTS AND DISCUSSION}

Generally, the most influential parameter in CCM is the casting speed. Simultaneously with the casting speed, the control system also corrects other quantities such as the mould oscillation frequency and cooling water flow rate into nozzles in the secondary cooling zone. Therefore, the influence of casting speed on other variables is complex and difficult to predict by simulation without a simultaneous operational measurement. Based on measurement and simulation during casting round blocks of diameter $520 \mathrm{~mm}$, responses to unsteady casting speed were analysed.

Figure 5 shows a 6-hour interval of casting. Besides casting speed $v$, also simulated strand temperatures are plotted, i.e., the surface temperature $t_{\mathrm{s}}$ averaged around a strand circumference and the centreline temperature $t_{\mathrm{c}}$, both evaluated at the end of the mould where the strand is not yet influenced by the secondary cooling zone. There were two non-standard states, the first at the time $6.03 \mathrm{~h}$ and the second at $7.3 \mathrm{~h}$ when speed of the strand withdrawal was reduced and stopped due to the breakout danger predicted by the system DGS.

The surface temperature response to the change in casting speed is complicated. Generally, a reduction in casting speed causes a gradual drop of surface temperature due to extended time available for cooling. In contrast, a complete stop of the strand withdrawal causes a gradual increase in surface temperature as the solid shell is shrinking, thermal resistance of the gap between the shell and mould is increasing, heat flux from the strand surface is decreasing and the solid shell is being reheated with high enthalpy of the strand liquid core. A following renewal of withdrawing causes initially an immediate drop in surface temperature due to a sudden restoration of the shell contact with the mould, followed by a steep increase in surface temperature due to shell shrinkage and reheating. Generally, the temperature peak after renewal of withdrawing is the higher the longer lasts the previous withdrawal interruption and the greater is the step of the casting speed change. Finally, the temperature gradually decreases to a stable value.

Figure 6 shows a detail of the first non-standard state at $6.03 \mathrm{~h}$. There was a speed reduction followed by three short stops and a final increase in casting speed which caused several periods of the surface temperature oscillation. In Figure 7 is a detail of the second non-standard state at $7.3 \mathrm{~h}$, which makes it possible to analyze the general behaviour described above more clearly. Reduction in casting speed at $7.35 \mathrm{~h}$ caused a drop of the surface temperature due to extending the time of cooling. The complete stop at $7.41 \mathrm{~h}$ caused a gradual increase in surface temperature due to the shell shrinking and reheating. The sudden short renewal of withdrawing at $7.45 \mathrm{~h}$ caused an initial rapid drop of the surface temperature followed by a gradual increase during next stopping at $7.48 \mathrm{~h}$. The second renewal of withdrawing at $7.61 \mathrm{~h}$ caused a temperature drop followed by a steep increase at $7.63 \mathrm{~h}$ and finally a gradual decrease at $7.65 \mathrm{~h}$ down to a stable value reached at $7.75 \mathrm{~h}$.

In Figure 8 are waveforms of casting speed and measured surface temperatures at three positions in the tertiary cooling zone where the strand is cooled by free convection and radiation. Optical pyrometers were placed at positions $5.3 \mathrm{~m}$ (pyrometer P1), $19.6 \mathrm{~m} \mathrm{(P2)}$ and $30.5 \mathrm{~m}$ (P3) from the steel level. P1 was about $3 \mathrm{~m}$ behind the last cooling nozzle. After stopping at $6.03 \mathrm{~h}$ the signals from all pyrometers were dropping due to the extended cooling time. As the cooling water flow rate into nozzles was not reduced enough during stopping, the part of the strand located in the secondary zone was

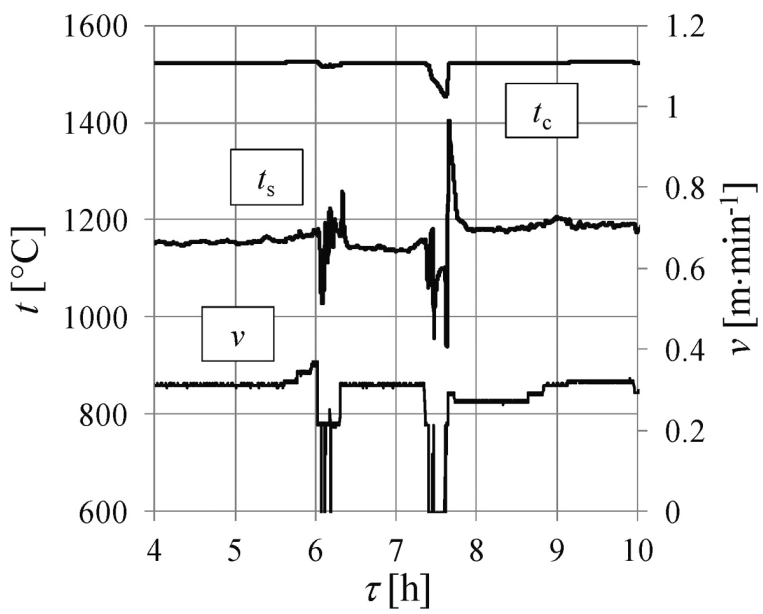

Figure 5: Strand temperatures at the mould exit and casting speed

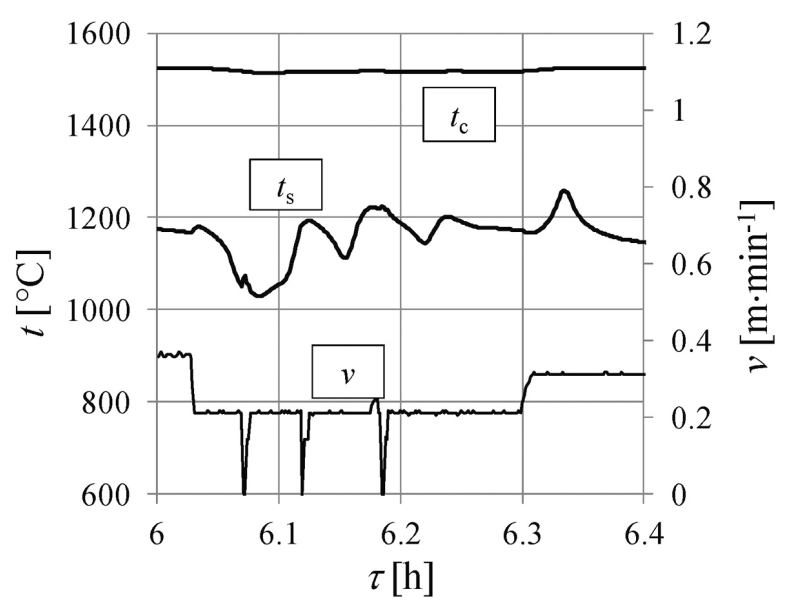

Figure 6: Detailed interval of the first non-standard state 


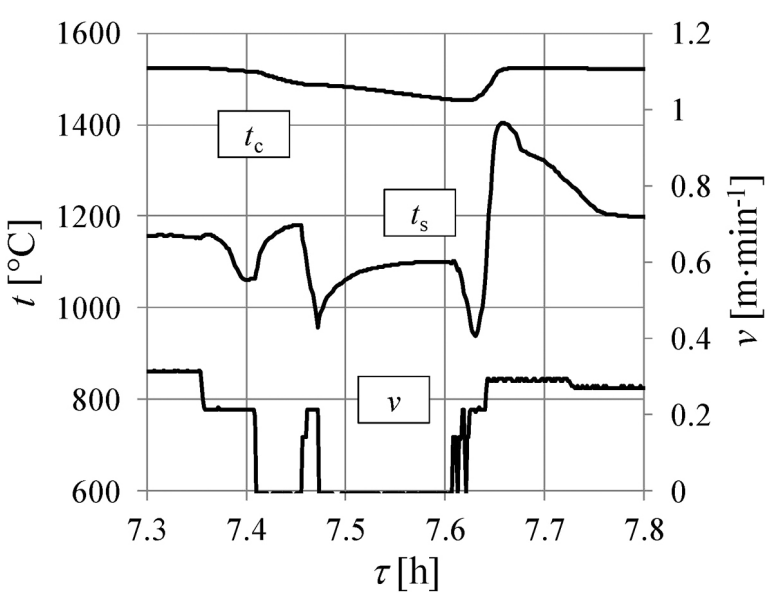

Figure 7: Detailed interval of the second non-standard state

undercooled. At $6.2 \mathrm{~h}$ this part came to P1 and caused further dropping of the P1 signal. The signal of P2 later at $7.1 \mathrm{~h}$ dropped similarly when the same undercooled part came to P2. Similarly, would react P3, but the response of P3 was simultaneously influenced by the second non-standard state at $7.3 \mathrm{~h}$.

Undecooling is not favourable in terms of quality. This meant that the static control algorithm of the secondary zone did not react sufficiently. It should be improved or replaced by an optimal dynamic control method $^{10}$. Due to the time shift caused by the strand movement, the effect of the first non-standard state collided with the second non-standard state at $7.3 \mathrm{~h}$ in P1-P3 temperatures. Nevertheless, the temperature drop of $\mathrm{P} 1$ at $7.7 \mathrm{~h}, \mathrm{P} 2$ at $8.8 \mathrm{~h}$ and $\mathrm{P} 3$ at $9.3 \mathrm{~h}$ due to the strand undercooling is visible.

Figure 9 shows the time dependence of the simulated solid shell thickness $s$ at the exit of the mould and at the pyrometer P1. The shell thickness was evaluated as an average distance between the surface and the node with $100 \%$ of solids. An increase in shell thickness was greater during the second non-standard state at $7.3 \mathrm{~h}$ when stopping took longer than during the first abnormal state.

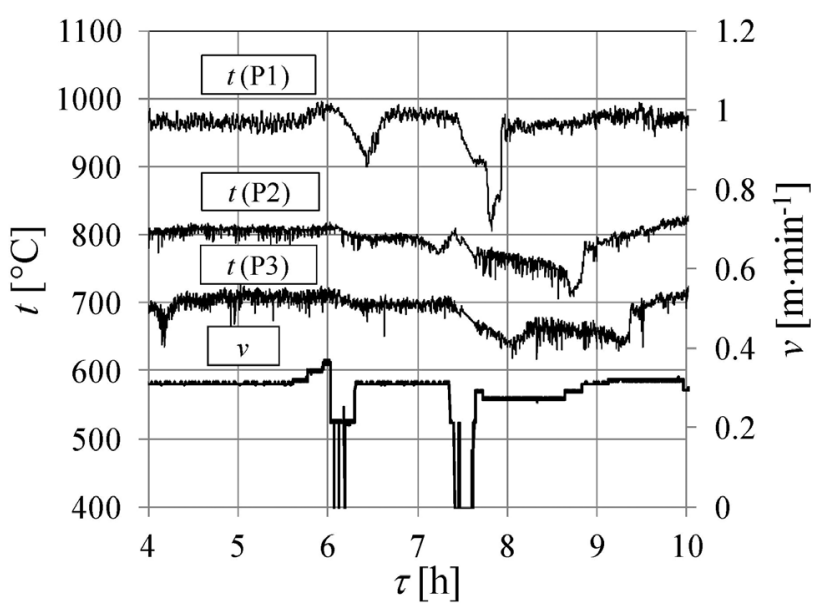

Figure 8: Surface temperatures measured by optical pyrometers

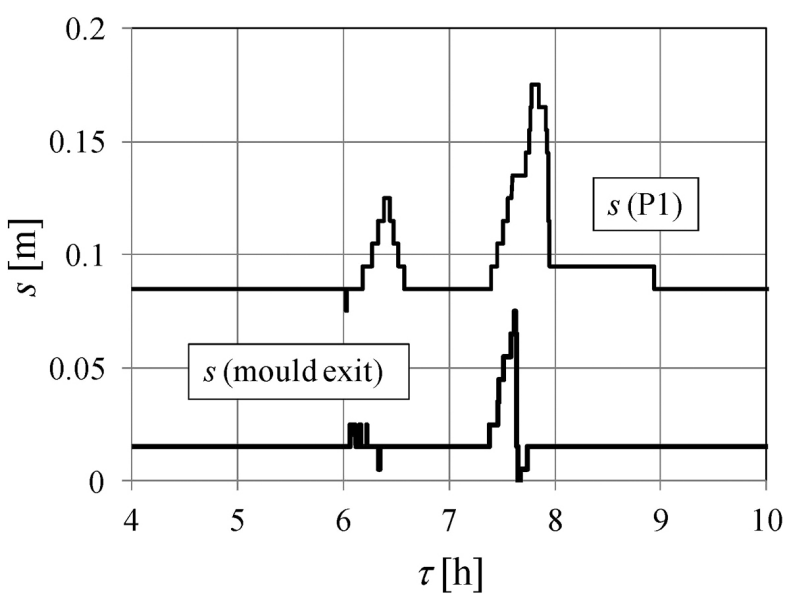

Figure 9: Simulated shell thickness

Figure 10 presents a waveform of metallurgical length based on the simulation. Generally, at steady conditions applies the higher casting speed the longer metallurgical length. But the behaviour of the metallurgical length after a sudden change in casting speed is more complex. After the stop of withdrawing at $6.03 \mathrm{~h}$ the metallurgical length slowly decreased, which was caused by extension of the cooling time. After restoring withdrawing at $6.2 \mathrm{~h}$, metallurgical length initially remained constant since the velocity of solidification approximated casting speed. About at $6.6 \mathrm{~h}$, however, the metallurgical length suddenly decreased. This was caused by a final solidification of the bounded region filled with the mushy phase surrounded by the solid phase, which may be considered as a "mini-ingot". After this the metallurgical length was slowly increasing up to the stable value at $7.1 \mathrm{~h}$, which corresponded to the current casting speed. The same phenomenon of the "mini-ingot" final solidification occurred at $8.0 \mathrm{~h}$ after the second non-standard state.

Phase maps of the strand at selected significant time points are pictured in Figure 11. White colour expresses the liquid phase, light grey colour corresponds to the mushy phase and dark grey represents the solid phase. The above mentioned mushy phase areas surrounded by

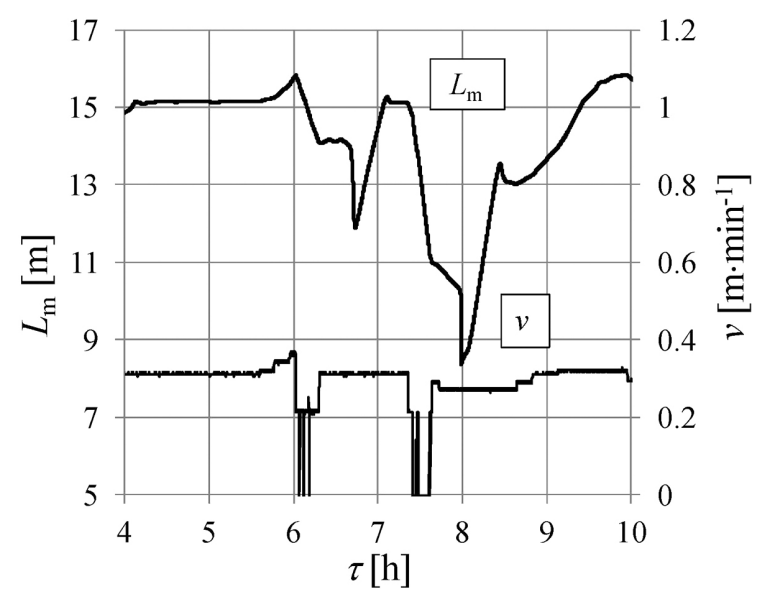

Figure 10: Simulated metallurgical length 

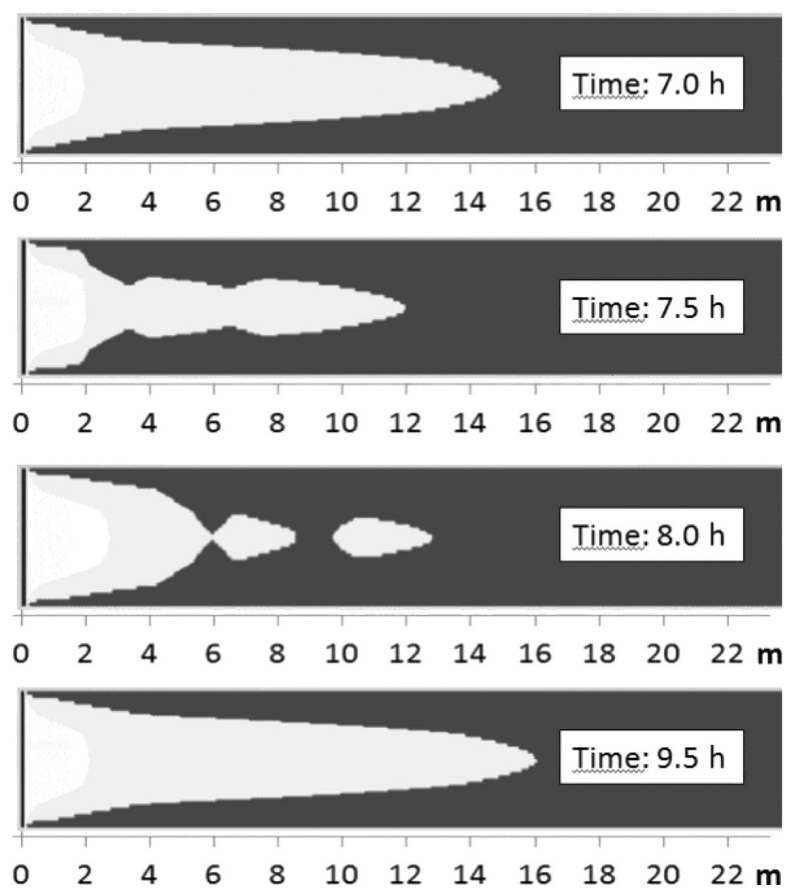

Figure 11: Phase maps during casting speed variation

the solid phase after the second non-standard state can be seen in the phase map of $8.0 \mathrm{~h}$.

The simulated surface temperatures at pyrometers positions P1, P2 and P3 are in Figure 12. The numerical model was tuned to calculate $20-30{ }^{\circ} \mathrm{C}$ higher surface temperatures in comparison to the values measured by the pyrometers to compensate an average temperature drop due to oxides and casting powder on the surface.

The simulated temperature waveforms were in good accordance with reality, but it is evident that simulated surface temperatures are smoother in comparison to the measured temperatures. The reason is that the simulated temperatures are responding only to changes in known casting parameters, e.g., casting speed and cooling water flow rate, while the surface temperatures in the real caster oscillate (Figure 8) due to a non-uniform layer of oxides and casting powder on the surface, and also due to spontaneous internal oscillation in the caster, either stochastic or quasi-periodical. Such oscillations are typical for multidimensional non-linear systems. Frequency analysis showed that the signals feature quasi-periods ranging from seconds to several minutes. A correlation analysis proved occasional relationship between surface temperature and some variables such as temperatures in the mould wall or liquid steel level.

It is generally difficult or even impossible to derive sufficiently detailed immediate boundary conditions for the numerical model to simulate the exact oscillation of the temperature field. Therefore, it is appropriate to combine several diagnostic methods based on the thermal numerical modelling and monitoring temperatures and other variables of the caster internal state for a purpose of the process control and quality prediction.

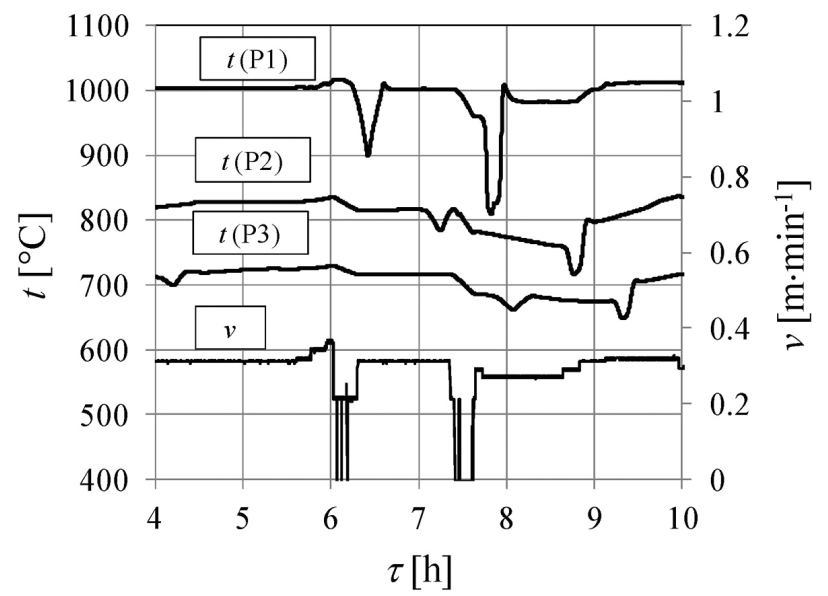

Figure 12: Simulated surface temperatures

\section{CONCLUSIONS}

An investigation of the unsteady states of the continuous casting process has been conducted using the process diagnostic system DGS, special measurement devices and a thermal numerical model. The responses in quantities induced by the casting speed variation were simulated and analysed, based on real measured data from a round block caster with a diameter of $520 \mathrm{~mm}$. The strand surface temperature oscillation was excited after a change of casting speed. The peak of surface temperature was the higher the longer lasted the withdrawal interruption and the higher was the casting speed step change. The metallurgical length behaviour after a temporary stop of withdrawing was also analysed and creation of "mini-ingots" was predicted. Due to the multidimensional and non-linear character, the system of the casting machine tends to be unstable and quantities in a caster are susceptible to oscillate. Knowledge of the cause and magnitude of the process variation is important for the casting control and quality prediction.

\section{Acknowledgements}

This paper originated with the financial support of grants MPO ČR No. FT-TA4/048, GAČR No. GA106/ 07/0938 and VŠB - TU Ostrava research projects SV2017/37 and SV2017/58. The authors are also grateful to companies DASFOS, v.o.s. and Třinecké železárny, a.s. for their cooperation in operational experiments.

\section{REFERENCES}

${ }^{1}$ Y. Zhang, M. Dudzic, V. Vaculik, Integrated monitoring solution to start-up and run-time operations for continuous casting, Annual Reviews in Control, 27 (2003) 2, 141-149, doi.org/10.1016/ j.arcontrol.2003.10.002

${ }^{2}$ J. Štětina, L. Klimeš, T. Mauder, F. Kavička, Final-structure prediction of continuously cast billets, Mater. Tehnol., 46 (2012) 2 , 155-160, http://mit.imt.si/Revija/izvodi/mit122/stetina.pdf 
${ }^{3}$ J. Štetina, T. Mauder, L. Klimeš, F. Kavička, Minimization of surface defects by increasing the surface temperature during the straightening of a continuously cast slab, Mater. Tehnol., 47 (2013) 3, 311-316, http://mit.imt.si/Revija/izvodi/mit133/stetina.pdf

${ }^{4}$ R. Čada, Formability of deep-drawing steel sheets. Proc. of the $5^{\text {th }}$ European Conf. on Advanced Materials and Processes and Applications (EUROMAT 97), Maastricht, 1997, 463-466

${ }^{5}$ R. Pyszko, L. Cudzik, R. Barabáš, P. Fojtík, M. Adamik, Advanced Process Monitoring Systems for Continuous Processes, Proc. of the 16th Triennial World Congress of International Federation of Automatic Control, Prague, 2005, doi:10.3182/20050703-6-CZ-1902. 01209

${ }^{6}$ R. Pyszko, M. Příhoda, P. Fojtík, M. Kováč, Determination of heat flux layout in the mould for continuous casting of steel, Metalurgija, 51 (2012) 2, 149-152, http://hrcak.srce.hr/74833
${ }^{7}$ Z. Franěk, M. Masarik, J. Šmíd, Practical utilization of analytical software instruments at optimisation of production of continuously cast slabs, Proc. of the $20^{\text {th }}$ International Conference on Metallurgy and Materials METAL, Brno, 2011, 55-60

${ }^{8}$ Z. Franěk, M. Masarik, J. Šmíd, Determination of the cause of the formation of transverse internal cracks on a continuously cast slab, Mater. Tehnol., 49 (2015) 2, 285-290, doi:10.17222/mit.2013.224

${ }^{9}$ M. Chabičovský, M. Hnízdil, A. Tseng, M. Raudenský, Effects of oxide layer on Leidenfrost temperature during spray cooling of steel at high temperatures, International journal of heat and mass transfer, 88 (2015), 236-246, doi:10.1016/j.ijheatmasstransfer.2015.04.067

${ }^{10}$ J. Štětina, T. Mauder, L. Klimeš, Utilization of Nonlinear Model Predictive Control to Secondary Cooling during Dynamic Variations, Proc of AISTech - Iron and Steel Technology Conference, Pittsburgh, 2016, 1517-1530 